MATEC Web of Conferences 9, 05003 (2013)

DOI: $10.1051 /$ matecconf/20130905003

(C) Owned by the authors, published by EDP Sciences, 2013

\title{
EPS insulated façade fires from a fire and rescue perspective
}

\author{
M. Kumm ${ }^{1, a}$, J. Söderström ${ }^{1}$ and A. Lönnermark ${ }^{1,2}$ \\ 1 Mälardalen University, Sweden \\ 2 SP Technical Research Institute of Sweden
}

\begin{abstract}
This paper highlights the challenges the fire and rescue services can meet at façade fires involving EPS insulation during construction and use of a building. The EPS characteristics are discussed in respect to the fire and rescue operation and results from orientating fire tests performed at a fire and rescue services training and test field are presented. Types of evacuation solutions, involving the fire and rescue services, where façade fires can delay or completely rule out the possibilities for safe evacuation, are presented. The restrictions in the Swedish building codes regarding use of combustible insulation are analysed and reflections over the practical problems with following the instructions to keep an EPS insulated façade safe through the building's whole lifespan are made. A number of occurred fires involving EPS are discussed and analysed from a fire and rescue perspective. Finally, recommendations are given for the fire and rescue services and future research fields are proposed.
\end{abstract}

\section{INTRODUCTION}

In order to save energy and simplify the installation work activities, insulation material for façades more and more often is changed from the more traditionally used stone or glass wool to expanded polystyrene (EPS) or other types of combustible types of insulations. The use of EPS is in many cases very favourable; it is light, easy to install and has a low coefficient of heat transmission. But the increased use of EPS in façades creates new challenges for the fire and rescue services. The challenges can mainly be divided into four main topics; fire and rescue service aided evacuation through windows in multistorey apartment buildings, fire spread between buildings and along façades, fire extinguishment and increased heat exposure on the fire fighters. At a fire scene the Incident Commander (IC) will have to make many decisions that will be affected by the actual conditions. Enclosure fires are daily work for an urban fire and rescue service, but risk assessment and strategic decisions are based on earlier experiences and traditional building technology. The use of EPS in façades can create fast fire spread both along a façade and between buildings and put both inhabitants in need of rescue and the fire fighters at risk. Furthermore, at a construction site larger quantities of EPS can be openly exposed and represent a higher risk of ignition both applied on facades and at open storages before installation.

\section{POLYSTYRENE BURNING CHARACTERISTICS AND THE AFFECT ON THE FIRE FIGHTERS}

The time to ignition for a material exposed to radiation depends on the level of radiation, i.e. for an increased radiation the ignition time decreases. In the other end of the scale the ignition time increase so that below a certain radiation level ignition does not occur, at least not within a specific and long time period of exposure. This minimum radiant heat flux, $\dot{q}_{\min }^{\prime \prime}$, is actually defined as the minimum heat

\footnotetext{
ae-mail: maria.kumm@mdh.se
}

This is an Open Access article distributed under the terms of the Creative Commons Attribution License 2.0, which permits unrestricted use, distribution, and reproduction in any medium, provided the original work is properly cited. 
Table 1. Heat of combustion [4].

\begin{tabular}{|l|l|l|}
\hline Material & $\boldsymbol{\Delta}_{\mathbf{h c}}$ Gross [MJ/kg] & $\boldsymbol{\Delta}_{\mathbf{h c}}$ Net [MJ/kg] \\
\hline Polystyrene foam & 39.7 & $35.6-40.8$ \\
\hline Polystyrene foam FR & $41.2-42.9$ & \\
\hline
\end{tabular}

flux needed for the surface temperature to reach the ignition temperature, $\mathrm{T}_{\mathrm{ig}}[1]$ and can be determined experimentally for different materials. Cleary and Quintiere performed tests in a cone calorimeter and found that $\dot{q}_{\min }^{\prime \prime}$ was $15 \mathrm{~kW} / \mathrm{m}^{2}$, for polystyrene foam, both expanded and extruded, fire retarded and non-fire retarded [2]. In another study, also with the cone calorimeter, Dillon analysed two different fire retarded polystyrene foams (EPS) and reached of $8 \mathrm{~kW} / \mathrm{m}^{2}$ and $23 \mathrm{~kW} / \mathrm{m}^{2}$, respectively [3]. In these cases the thermal properties of the materials differed, i.e. the thermal inertia $(k r c)$ was different. This was also the case for the material tested by Cleary and Quintiere, which could explain that the fire retarded and the non-fire retarded showed the same characteristics. If the non-fire retarded value is left out, the following expression can be used:

$$
\dot{q}_{\min }^{\prime \prime}=27.2 \cdot(K p c)^{-0.5}-13.4 \text {. }
$$

The energy content in polystyrene foam is higher than in most other insulation or building materials and the temperatures reached from EPS fires higher than in traditional building materials [4].

In literature few and unsecure values can be found regarding the radiant heat flux from EPS façade fires. Most found radiant heat flux values describe the conditions from openings, like windows or balconies, at fully developed fires and not from burning facades at all. The radiant heat flux a fire fighter is estimated can work in is $5 \mathrm{~kW} / \mathrm{m}^{2}$, based on tests performed at SP The Technical Research Institute of Sweden 1990 (The Swedish National Testing and Research Institute) including radiant heat flux exposure on fire fighters [5]. Most estimations regarding tolerated heat flux is based on these tests. As the tests were performed more than a decade ago and the development of the fire and rescue protective clothing has evolved there is a need for complementary systematic tests in this field. As both the radiant heat flux from EPS façade fires and the tolerated heat flux is difficult to estimate the conclusions on effect in this area on the fire fighters have to be made from real fire experiences. Compilation from the fire and rescue services experiences from Swedish EPS fires though indicate that the radiant heat flux has been an area of concern, even if not as much as the smoke production [6].

In case of fires in neighbouring buildings or for example in storage material at construction sites, the radiant heat flux can make exposed EPS to ignite. At real fires also covered EPS insulation have been seen melting inside the construction, flow down inside the construction and cause pools of melted EPS close to the wall at ground level $[6,7]$. Many EPS materials have a melting point around $320^{\circ} \mathrm{C}$. Melted EPS can in these cases cause pool fire like conditions or if not ignited still represent a potential hazard for the evacuation, the fire fighters or the building.

Burning EPS produces large amounts of smoke and the toxicity is higher than in smoke from traditional building materials [8-12]. Both the toxicity and the obscured view can cause problems and at occurred fires in Sweden it is not uncommon that habitants in surrounding housing environments are guided to stay inside and close windows and ventilation [6]. The smoke can also cause harm to fire fighters, not wearing BA (breathing apparatus) systems, outside the building at the scene of fire. Even relatively small quantities of smoke cause irritation in the respiratory system and repeated exposure can cause secondary damage [13].

\section{THE FIRE AND RESCUE SERVICE'S STRATEGY AND TACTICS}

In Sweden the fire and rescue services mission, obligations and rights are regulated in the Swedish Civil Protection Act (Lagen om skydd mot olyckor) [14]. The national objectives consider equivalent, 
$1^{\text {st }}$ International Seminar for Fire Safety of Facades, Paris (France), 2013

satisfactory and comprehensive provisions to save life, property and the environment, with consideration given to local conditions. The fire and rescue services should be performed within acceptable time using effective methods. The strategies at the individual accident can be either fighting the fire or not fighting the fire, depending on the available resources or the type of fire and special conditions at the scene of the accident. As saving lives always is the fire and rescue services first priority, limited resources in combination with a fast and fierce fire development could imply a tactic decision not to fight the fire in favour of assisting the evacuation. On the other hand another possible tactic decision could of course be to fight and put out the fire in order to save people inside the building. The main evacuation strategy when designing Swedish buildings is self-evacuation, with a few exceptions.

\section{FIRE AND RESCUE SERVICE AIDED EVACUATION THROUGH WINDOWS}

Fire and rescue service aided evacuation from windows are allowed in Swedish buildings in the occupancy class 1 (offices, industries) and for occupancy class 3 (dwellings) with the window opening's lower end placed on maximum 23 meter [15]. The evacuation strategy can be used if the fire and rescue services have a sufficiently fast response time and sufficient capacity. In practical it means a response time less than ten minutes, except for one and two storey buildings where response times up to twenty minutes can be considered. The capacity of the fire and rescue services is described in the municipal plan of actions for accidents, based on the requirements in the Swedish Civil Protection Act (2003:778). Enough capacity, in the intention of the legislation, is the combination of sufficient equipment and staffing. Equipment needed could for example be a ladder fire truck for evacuation from locations with the window on heights between 11 and 23 meter, where the portable extension ladders no longer reach. Fire and rescue service aided evacuation for windows placed over 23 meters is not allowed and other solutions have to be designed. For locations in occupancy class 1 not more than 15 persons from each fire compartment should be designed for when using fire and rescue aided evacuation strategies.

Compared to self-evacuation fire and rescue service aided evacuation always consumes more time. In areas with limited staff resources, even if it fulfils the level of capacity to allow evacuation through windows, it can restrict the fire and rescue services from other parallel tasks like extinguishing the fire.

As apartments should be EI 60 separated fire compartments, the inhabitants should be able to safely stay in their homes if the normal emergency exit from multi-storey apartments - the staircase - is filled with smoke, until rescued by the fire and rescue services. In case of a façade fire, especially fires involving EPS with higher radiant heat flux and faster fire spread, the inhabitants can be trapped between the smoke-filled staircase and the burning façade as fire and rescue service aided evacuation could be very difficult. In urban areas, with high capacity fire and rescue services and under normal conditions, the ventilation of the staircase will be possible within the available time frame before smoke or fire spread into the adjacent apartments.

Many older Swedish dwellings are also ventilated only by exhaust air systems with intake air through trickle vents underneath the window. Fans in operation during the full time requirement for the fire compartment can be used as a protection method to prevent smoke spread between apartments. The method allows smoke to enter the ventilation system but not to spread into adjacent fire compartments. This means that the system cannot be shut off without the risk for smoke spread from the enclosure fire to other unaffected apartments in the building. If an enclosure fire spreads to the façade, the under pressure in other apartments, created by the ventilation system, can make smoke from the façade fire spread into earlier unaffected apartments, see Figure 1.

At façade fires also the risk for windows breaking due to outside heat exposure is higher than if windows in unaffected apartments only are exposed to the flames and smoke through the window in the enclosure fire. 


\section{MATEC Web of Conferences}

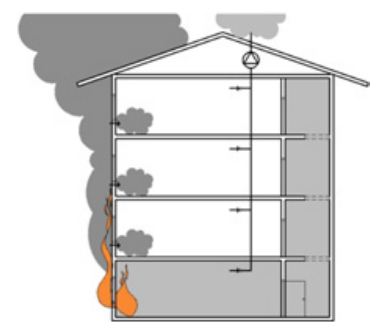

Figure 1. Illustration of possible smoke spread at façade fires in dwellings with exhaust air systems and fans in operations in case of fire.

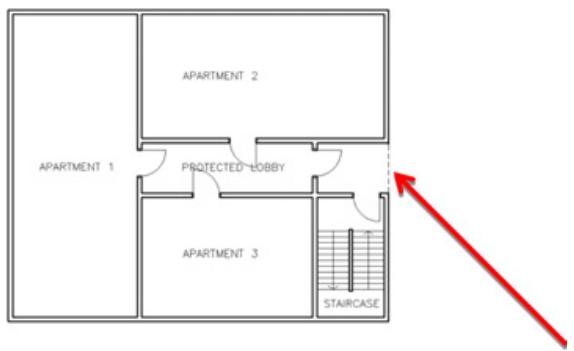

Figure 2. Example of design solution of a $\operatorname{Tr} 1$ staircase with open passage from the protected lobby to the staircase.

\section{SELF-EVACUATION THROUGH TR1-STAIRCASES}

In up to 16 storey buildings a $\operatorname{Tr} 1$ staircase is allowed to be the only escape route in occupancy classes 1 and 3. A Tr1 staircase should be designed with a separating structure of at least EI 60 to limit fire and smoke spread [15]. One commonly used possible solution of preventing smoke from spreading from the apartments through the protected lobby to the staircase is an connecting lobby open to the façade, see Figure 2. In case of a façade fire the escape through the Tr1 staircase can be difficult or even impossible. $\operatorname{Tr} 1$ staircases as the only evacuation route can be used for example if the near surrounding around the building does not allow the fire and rescue services reach with the ladder engine, if the fire and rescue services does not have the required capacity or if the building is too high for fire and rescue service aided evacuation through windows. In higher buildings with $\operatorname{Tr} 1$ staircases, windows does not need to fulfil the requirements for windows used for evacuation and windows can be designed without opening possibilities. In case of a rapid fire development along the façade persons can be trapped at floors above the fire and the fire create an unwanted situation both for the persons in need of rescue and for the fire and rescue services.

\section{Requirements on exterior Walls regarding to the Swedish building codes}

Façade linings must only to a limited extent contribute to the heat and smoke development in case of fires. Limited extent in the meaning of the building codes is that that the possibilities for safe evacuation should be maintained as well as the fire suppression capability. In Br1 buildings (generally three storey buildings or higher) the exterior walls should be designed so that the fire compartments remain intact, the fire does not spread inside the wall construction, the risk for fire spread along the façade is limited and parts falling off the façade at fires only to a limited extent put persons located close to the façade at risk. For $\mathrm{Br} 3$ and $\mathrm{Br} 2$ buildings (generally one and two storey buildings) the requirements are lower and only limited fire spread along the façade is regulated. One way to show the fulfilment of the requirements 
in the building codes is to tests the façade construction according to the test standard SP FIRE 105 issue 5 [15].

Many of the ETICS (External Thermal Insulation Composite Systems) have passed the SP FIRE 105 tests, but still EPS based façade systems in some cases cause fire spread and smoke production that are contradictive to the aim in the regulations. The causes can be divided in four main groups;

1. Fires under construction - the EPS insulation is not yet covered with its final cladding or surface finish and consequently not yet protected against fire.

2. Sections of the system need to be welded when installed. During welding sparks or heat transfer to sensitive parts of the system ignite the EPS.

3. The ETICS has not been installed according to the instructions and exposed EPS is ignited from a fully developed enclosure fire.

4. The cladding or surface finish has been damaged, has got a production fault or has cracked by age and exposed EPS is ignited from a fully developed enclosure fire.

\section{FIRES UNDER CONSTRUCTION AND THE BUILDERS RESPONSIBILITIES}

Construction sites, like all other occupancies, should according to the Swedish Civil Protection Act [14] work systematically with their fire protection and their preparedness in case of accidents. The working environment and work safety is also regulated in the Swedish Work Environment Act and its provisions [16]. Inspection of companies and occupancies according the Civil Protection Act is performed by the fire and rescue services. Not all occupancies are submitted to inspection and construction sites, especially normal size construction sites with moderate completion times, does not necessarily become an object for inspection. Lack of inspection does not release the occupation from its obligations, but the awareness of the own construction site's risks and need of fire prevention does vary between different construction sites [17].

During the installation large quantities of exposed EPS can be stored in connection to the building. Both hot works like welding, cutting or soldering or arson represent possible ignition sources. Already at the planning phase the risks, logistics and fire prevention measures should be described in the safety documents and on the construction site outline. The risks of exposed EPS both at storages and on the façade itself should be communicated with the construction workers and incorporated in the internal safety inspections. Special precaution should be taken when welding sections of construction elements containing EPS and the need of extra surveillance during and after the welding should be evaluated.

The installation of EPS façade elements is often favourable from a workload perspective. A fire during construction can however put both construction workers and the fire fighters at risk. The amount exposed EPS should be kept as low as possible and storage should be kept away from the building. Only the amount of EPS mounted during each work shift should be transported into the building at a time and the logistics closely checked upon by the staff management.

Building construction involves many disciplines and delays in one field often affect others with high costs as a consequence. Even if the EPS insulation are energy efficient and light at installation, the total cost, in lives, health, property and the environment can be high if not installed correctly. The instructions need to be clear and the risks during installation and if not mounted correctly should not be hidden but highlighted. Special care should be taken at building projects where occupation is allowed in stages and housing and construction co-exists.

\section{EXPERIENCES FROM OCCURRED EPS FIRES DURING CONSTRUCTION}

The recent fire at Karlstad hospital in Sweden shows the need of precaution when fitting construction elements containing EPS. A fire started during the welding of the elements and more than 60 patients and staff were evacuated for safety reasons. The fire started in the middle of the parallel weekly 


\section{MATEC Web of Conferences}

construction meeting and the fire and rescue services had the unique opportunity to be assisted by all consultants providing knowledge and drawings of the building. The fire was relatively easy to get under control, partly because of the guidance from the gathered experts that could provide information of the construction sites strengths and weaknesses [18]. Welding or other dangerous hot works is a common fire starter at construction sites. Even relatively small construction works can cause large damages, as the fire in Sollentuna outside Stockholm in 2003. Welding of water pipes inside an apartment conducted heat to combustible insulation that ignited and caused damages for nearly 50 MSEK [19].

\section{FIRES UNDER USE OF THE BUILDING AND THE OWNERS RESPONSIBILITIES}

If the ETICS/EPS wall systems have not been installed properly or if the surface material have been damaged an ordinary enclosure fire in the building can ignite the façade material when the flames and convective heat flux reach out through the window. The façade material is supposed to withstand weather, wind and mechanical impact during the full life span of the building. Experiences from occurred fires show that also a minor damage that punctures the protective surface can be a risk in case of fire. Since exposed EPS can cause so severe damage it is important that the owner of the building running includes inspections of the façade material in the systematic fire prevention work. According to the Swedish Civil Protection Act the owner or beneficiary should perform reasonable precautions to prevent fires or to minimize the consequences in case of fire [14].

\section{EXPERIENCES FROM OCCURRED EPS FIRES DURING USE}

In a fire in a seven storey high apartment building in Berlin, 2005 [20] flames spread along the façade causing a complex situation both from an evacuation and fire and rescue perspective. When the fire brigade arrived, approximately 9 minutes after receiving the alarm, intense flames were spreading in the façade over several floors. Some of the residents had managed to reach a safe haven, although for a significant number of people the main evacuation route, the staircase, could not be used because of the progressive fire spread and smoke production. Several residents called for help in the windows in the apartments facing away from the fire. In total 10 persons were evacuated with assistance of the fire brigade. The fire started in an apartment on the $2^{\text {nd }}$ floor and spread vertically along the façade to the $5^{\text {th }}$ floor. The wall construction, from the interior side, consisted of; $150 \mathrm{~mm}$ concrete, $25 \mathrm{~mm}$ chipboard, $80 \mathrm{~mm}$ polystyrene and two layers of plaster with reinforcement (glass fibre) in between. The façade had incombustible barriers on the second and fourth floor in order to prevent fire spread along the façade. The EPS however melted and flowed along the façade and over bridged the barriers. The Berlin fire is a good example where the fire and rescue services had to concentrate on the evacuation in favour of fighting the fire. Two persons were deceased in the fire and 3 persons were hospitalised.

It is known that the combustible material, particular when being exposed, can contribute to a fast developed and intense fire with heavy smoke production. An example of this is a fire involving EPS in an underground garage in Vallentuna in 2007 [21]. The fire started in unprotected EPS in the ceiling ignited by fireworks, brought into the garage and lit by two young men. Due to a fire a couple of years earlier the protection boards, damaged by the earlier fire, were dismounted in order to be replaced. The renovation was not yet finished and approximately $800 \mathrm{~m}^{2}$ of the EPS was exposed. 20 persons were taken to hospital due to smoke inhalation and one elderly man, trapped in his car, was found deceased.

Both these fires show that the use of EPS in facades and other structures needs to be considered and that the relatively easy ignition and production of toxic smoke can contribute to an unwanted outcome of the fire. 


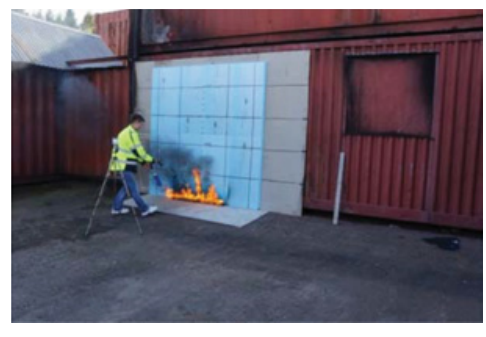

Figure 3. Ignition.

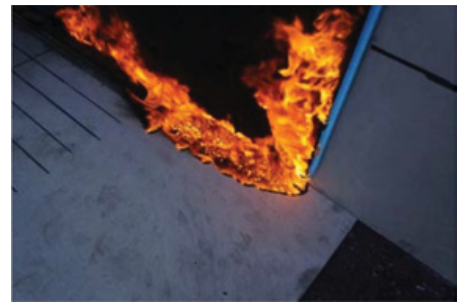

Figure 4. Melting EPS.

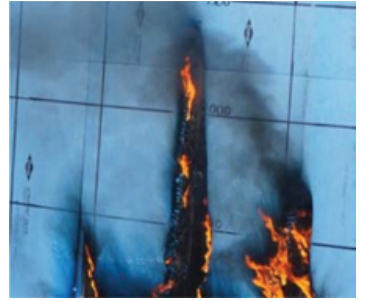

Figure 5. Flame spread in air gap.

\section{FIRE SPREAD BETWEEN BUILDINGS}

Distances and/or fire resistance in exterior walls can limit fire spread between buildings. Swedish building regulations [11] describe minimum distances between buildings and maximum total area for groups of 1-2 storey family houses. The regulations are mainly based on tests regarding fire spread between concrete and light-concrete buildings performed in the late '70s and early ' 80 s [22, 23] and radiant heat flux calculations based on fires in wooden buildings, not houses with EPS insulated façades [24]. Fire spread between buildings is mainly caused by radiant heat flux or sparks travelling with the wind. EPS façade fire represents a larger source of radiation than fires in traditional building materials, but the lack of exact values makes calculations and recommendations difficult.

\section{ORIENTATING FIRE TESTS}

To get a foundation for further tests, orientating fire tests were performed at the fire and rescue services test and training field in September 2013. The orientating fire tests will be base for later performed systematic fire tests during the autumn 2013. In hardware stores EPS insulation boards are classified in respect to compressive strength. Both lightweight EPS boards without fire retardants with low compressive strength and bevelled fire retardant façade boards with higher compressive strength can be found on the market. The normal compressive strength is between 80 and $200 \mathrm{kPa}$ short-term load. The tests were performed with $50 \mathrm{~mm}$ S80 fire retardant boards with $80 \mathrm{kPa}$ short-term compressive strength (10\% deformation) and $24 \mathrm{kPa}$ long-term strength ( $2 \%$ shrinking). The EPS boards were mounted on non-combustible fiber silicate boards on a surface of 2,4 $\times 2,4$ meter. The boards were ignited by an 1 meter beam with the dimensions $25 \times 50 \mathrm{~mm}$ soaked with $1 \mathrm{dl}$ of heptane to imitate the first flames exiting the window from an enclosure fire, see Figure 3.

The main parameters that influenced the flame spread upwards were the thickness of the EPS boards (one, two or three layers) and the size of the air gap between the boards. The orientating test showed that even thinner $(50 \mathrm{~mm}$, one layer) EPS boards created large amounts of smoke even in those cases the EPS melted quickly and created areas without EPS that prevented flame spread upwards, but instead flowed down on the ground and created pool fire conditions, see Figure 4, see Figure 5. At multiple layers the flames instead spread fast upwards. In those cases the boards were mounted with a small air gap between the boards, the flames spread upwards faster in the air gaps than at the surface.

\section{DISCUSSION AND CONCLUSIONS}

Existing tactics and methodology for façade fires are based on traditional building materials. The latest decade's fires in facades with combustible insulation show the need for development of improved risk evaluations and extinguish tactics. In cases with fast fire spread and limited resources, the IC can need to chose between the decision to extinguish the fire or to save people at risk. The knowledge prior a fire if or 


\section{MATEC Web of Conferences}

if not a specific building contains combustible insulation does not commonly reach the fire and rescue services on beforehand. Occurred incidents and accidents pinpoint the need of adequate information about both the building and its structure and the fire itself.

From a fire safety perspective EPS as insulation material in facades can be debatable especially in dwellings when windows is used as the secondary escape route. EPS has many advantages regarding energy efficiency and workload during construction, but much more consideration must be taken to ensure a safe installation and adequate control functions during the full life span of the building. To improve the possibilities to prevent future fires in EPS insulated façades and to mitigate the consequences in the fires that nevertheless occur, measures must be taken at all levels from the manufacturer via the constructor and the owner of the building to the first responders.

1. ETICS as a system are usually tested and found to fulfil the requirements in SP FIRE 105, but the chain is only as strong as its weakest link. In order to ensure an installation that meet the demands in the building codes, certification of the individual construction worker could be considered. Fire safety and EPS fire behaviour should be a self-evident part of the education.

2. Storages of large quantities of EPS during construction should be avoided and only the amount of EPS used during a work shift should be allowed on scaffolds and open or unprotected parts of the building. During construction the final fire protection solutions is not yet installed, but the risks for fires are higher than when the building later is taken in use.

3. The area of exposed EPS at facades and other construction parts should be kept as low as possible for as short time as possible.

4. Hot works, like welding or cutting, should not be allowed in the close surrounding of exposed EPS. If installation of the EPS wall systems not can be performed without welding, extra fire surveillance should be considered.

5. Inspection of the EPS insulation façade should be performed with respect to fire safety, both when finishing the construction phase and during the use of the building.

6. Incombustible barriers in facades must be designed so melting EPS does not eliminate the function of the barrier.

7. Combustible insulation should not be allowed close to open balconies in $\operatorname{Tr} 1$ staircases.

8. Adequate, but easy-to-understand, information about construction and façade materials should be handed over to the fire and rescue services, especially in buildings where the fire and rescue services are counted for in the evacuation strategies.

Both the radiant heat flux from EPS façades and the fire fighters tolerated heat flux during working conditions would need to be further investigated. The results from façade heat flux measurements could also later be used for complementary calculations regarding fire spread between buildings.

\section{References}

[1] Babrauskas, V., Ignition Handbook, Fire Science Publishers, Issaquah, WA, USA, 2003.

[2] Cleary, T. G. and Quintiere, J. G. "Flammability Characterization of Foam Plastics (NISTIR 4664), NIST (1991).

[3] Dillon, S. E. "Analysis of the ISO9705 Room/Corner Test: Simulations, Correlations and Heat

[4] Babrauskas, V., "Heat of Combustion and Potential Heat". In Heat Release in Fires (V. Babrauskas and S. J. Grayson, Eds.), E \& FN Spon, London, UK, 1995.

[5] Persson, H., "Basutrustning för skumsläckning - Försöksresultat och rekommendationer som underlag för dimensionering och utförande”, SP Swedish National Testing and Research Institute, SP RAPPORT 1990:36, Borås, Sweden (in Swedish), 1990.

[6] Kumm M, Söderström J, Arbetsdokument (Working document) - Sammanställning av räddningstjänstens erfarenheter från bränder i cellplast (In Swedish. Compilation of the fire and rescue services experiences from EPS fires), MDH-EST, 2013 
[7] Interview with Incident Commander A Palm, Greater Stockholm Fire Brigade, $21^{\text {st }}$ of August 2013

[8] Stec, A., and Hull, R., Eds., "Fire toxicity," Woodhead Publishing Limited, Cambridge, UK, 2010.

[9] Lönnermark, A., Stripple, H., and Blomqvist, P., "Modellering av emissioner från bränder", SP Sveriges Provnings-och Forskningsinstitut, SP Rapport 2006:53 (in Swedish), Borås, 2006.

[10] Hertzberg, T., Blomqvist, P., Dalene, M., and Skarping, G., "Particles and isocyanates from fires", SP Swedish National Testing and Research Institute, SP Report 2003:05, Borås, Sweden, 2003.

[11] Butler, K. M., and Mulholland, G. W., "Generation and Transport of Smoke Components", Fire Technology, 40, 149-176, 2004.

[12] Tewarson, A., "Generation of Heat and Chemical Compounds in Fires". In The SFPE Handbook of Fire Protection Engineering (P. J. DiNenno, D. Drysdale, C. L. Beyler, W. D. Walton, R. L. P. Custer, J. R. Hall, and J. M. Watts, Eds.), National Fire Protection Association, 3-82-3-161, Quincy, MA, USA, 2002.

[13] Savolainen H, Kirchner. N: "Toxicological Mechanisms Of Fire Smoke", The Internet Journal of Rescue and Disaster Medicine, 1998 Volume 1 Number 1, DOI: 10.5580/9a4

[14] The Swedish Civil Protection Act - Lagen om skydd mot olyckor (2003:778)

[15] The Swedish Building Codes, 19 ${ }^{\text {th }}$ edition (BFS 2011:26), The Swedish National Board of Housing, Building and Planning, 2011

[16] The Swedish Work Environment Act - Arbetsmiljölagen (1977:1160) and provisions (AFS)

[17] Lindholm L, Cellplast som fasadisolering - Kan energieffektivitet och brandsäkerhet kombineras? (In Swedish. EPS as façade insulation. Can energy efficiency and fire safety be combined?) Bachelor Thesis (Working document), Mälardalen University, 2013

[18] Interview with Incident Commander M Palmquist, Karlstad Fire Department, $12^{\text {th }}$ of September 2013

[19] Fire Investigation Report, Kung Hans väg, Sollentuna, SOS 030205-01370, 2003

[20] Broemme A, Verheerender Fasadenbrand, Brandschutz Deutsche Feuerwehr-Zeitung, No 6, August 2005

[21] Fire Investigation Report, Södra Roslagens Fire Brigade, $11^{\text {th }}$ of February 2008

[22] Fredlund B et al., Skydd mot brandspridning inom småhusbebyggelse i lättbetong (Report in Swedish. Title translated to English: Prevention of fire spread between family houses in lightconcrete), The Swedish Fire Protection Association SFPA, 1977

[23] Fredlund B et al., Skydd mot brandspridning inom småhusbebyggelse i betong (Report in Swedish. Title translated to English: Prevention of fire spread between family houses in concrete), Report number R80-1, Lund University, 1980

[24] Flux Measurements (M.S. thesis). Univ. Maryland, College Park (1998). 